\title{
MARKET INTEGRATION AND PRICE TRANSMISSION OF BEEF IN THE ARCHIPELAGIC STATE: THE CASE OF THE PROVINCES IN INDONESIA
}

\section{Elifas Omega Yusufadisyukur*)1, Stephan von Cramon-Taubadel ${ }^{* *}$, Suharno ${ }^{* * *}$, and Rita Nurmalina***)}

*) International Agribusiness and Rural Development Master Program, IPB University

Jl. Kamper Wing 4 Level 3, Campus of IPB Dramaga, Bogor 16680, Indonesia

${ }^{* *}$ Department of Agricultural Economics and Rural Development, University of Goettingen

Wilhelmsplatz 1, 37073 Goettingen, Germany

${ }^{* * *}$ Department of Agribusiness, Faculty of Economic and Management, IPB University

Jl. Kamper Wing 4 Level 5, Campus of IPB Dramaga, Bogor 16680, Indonesia

\begin{abstract}
The Archipelagic state condition brings challenges to market integration and price transmission on two provinces market pairs within and between the island. The duration of price correction is essential to ensure market integration. Therefore, this study aims to assess the integration of domestic markets for beef within an island and between the island and analyze the speed of adjustment (the correction) of the prices by two provinces within the island and between the islands. These aims, daily frequency (weekdays) of Beef Consumer Prices (BCP) of 4 types of beef (Primary Cut, Secondary Cut AB, Meat Manufacturing and Fancy and Variety Meat) from 01 January 2015 to 27 April 2018 containing 28,611 observations were obtained. The data were analyzed using the Vector Error Correction Model (VECM). This study reveals that the island's provinces have fewer integrated than the pairs provinces located between islands by comparing 31 pairs with 38 pairs. It can be concluded that from research, the price correction in the pairwise province within an island is stronger than the pairwise between the islands, with $10.33 \%$ per day and $9.87 \%$ per day, respectively. This study recommends the government to formulate policies that carry out equitable development, especially those that facilitate access to the central beef production in Indonesia to avoid market exploitation and spread price information along with provinces in Indonesia, especially in eastern Indonesia.
\end{abstract}

Keywords: archipelagic state, market integration, Indonesia, beef, VECM

\begin{abstract}
Abstrak: Kondisi negara kepulauan membawa tantangan pada integrasi pasar dan transmisi harga pada pasangan pasar dua provinsi baik di dalam satu pulau maupun antar pulau. Durasi koreksi harga penting untuk memastikan integrasi pasar. Oleh karena itu, studi ini bertujuan untuk menilai integrasi pasar domestik untuk daging sapi di dalam pulau dan antar pulau serta menganalisis kecepatan penyesuaian (koreksi) harga di dua provinsi yang berada di dalam pulau dan antar pulau. Untuk mencapai tujuan tersebut, frekuensi harian (hari kerja) Harga Konsumen Daging Sapi (BCP) 4 jenis daging sapi (Potongan Primer, Potongan Sekunder AB, Daging Manufaktur dan Daging Fancy dan Varietas) dari 01 Januari 2015 hingga 27 April 2018 yang berisi 28.611 observasi telah diperoleh. Data dianalisis menggunakan Vector Error Correction Model (VECM). Studi ini menunjukkan provinsi-provinsi yang terletak di dalam pulau memiliki integrasi yang lebih sedikit daripada provinsi berpasangan yang terletak antar pulau dengan perbandingan 31 pasangan dengan 38 pasangan. Dari hasil penelitian dapat disimpulkan bahwa koreksi harga pada provinsi berpasangan dalam satu pulau lebih kuat dibandingkan dengan pasangan antar pulau yang masingmasing sebesar 10,33\% per hari dan 9,87\% per hari. Kajian ini merekomendasikan pemerintah untuk merumuskan kebijakan yang melakukan pemerataan pembangunan, terutama yang memfasilitasi akses ke sentra produksi daging sapi di Indonesia untuk menghindari eksploitasi pasar dan penyebaran informasi harga di seluruh provinsi di Indonesia, khususnya di kawasan timur Indonesia.
\end{abstract}

Kata kunci: Negara kepulauan, integrasi pasar, Indonesia, daging sapi, VECM

${ }^{1}$ Corresponding author:

Email: yusufadisyukur@gmail.com 


\section{INTRODUCTION}

The archipelagic state is like Indonesia, whose thousands of islands and territory divided into 1,811,570 square kilometer land area and approximately 3,081,756 square kilometer water area enclosed has its challenges in the process of distributing goods, including consumer goods such as agricultural commodities that can be consumed equally by the Indonesian people (World Bank, 2017). Some of the products are transported only with one land transportation, but some require at least two transportation modes, land and water or air.

The dynamics of consumer goods' distribution from certain geographical conditions possessed by the island nation allows the research on market integration and price transmission. In policy implications, to avoid errors in policy specifications, market integration has a vital role as a reference in determining the market level, detecting signs of price manipulation, and efforts to encourage structural transformation and technological adoption of increased productivity. So that the use of resources such as improving agricultural income for producers, widening the market for agricultural products, encouraging the growth of agriculture-based industries to support agricultural derivative products, encourage added value to meet market demand, and also create jobs by assessing the level of efficiency in interaction and interdependence between commodities that can be traded in different markets (Listorti and Esposti, 2012; Acquah and Owusu, 2012).

Rice as a staple food is a commodity has so far dominated research on market integration in Indonesia with co-integration analysis (Istiqomah et al. 2005; Suryaningrum et al. 2013) and various of vegetables; red chili, shallot, cabbage, potato, and tomato (Firdaus and Gunawan, 2012), shallot (Rahmawati et al. 2018), while commodities others were carried out by Chalil (2016, palm oil), Setianti et al. (2017, dairy milk), Nurhidayati et al (2015, ribbed smoked sheet/RSS) and Varela et al. (2012, cooking oil, rice, sugar, maize, and soybean).

Beef is an essential agricultural commodity that includes nine types of basic needs of the people. The development of beef production in Indonesia in 1984 2017 in aggregate tended to grow positively by $2.85 \%$ per year. Beef production in 2017 was 531.76 thousand tons, up $4.95 \%$ from 518.48 thousand tons in 2016. The increase in production was followed by an increase in prices by $1.96 \%$ from Rp. 113,555 in 2016 to Rp115,779 in 2017 with the highest price is Rp145,000 in Tanjung Pinang, and the lowest price is Denpasar Rp78,000 per $\mathrm{kg}$. Despite the increase in prices, it is expected that people's purchasing power will also increase along with the increase in GDP in the livestock sector at the same time so that consumption is also increasing by $3.85 \%$ (Indonesian Ministry of Agriculture, 2017).

So far, the researches on beef use prices as the focus of proper attention to government intervention towards price formation (Utami, 2016), and within the local scope with a retail market approach (Setiadi et al. 2012) and an analysis of the price volatility of beef in Indonesia (Dewi, 2016).

There is a gap in beef research in Indonesia regarding market integration of both the commodity per se and the model used. So far, the research on market integration for beef commodities still has limitations, such as; first, although it has already done to study in national scope by spatial market integration (Utami, 2016), studies may ignore critical regional considerations, since these studies do not evaluate all capital city markets within provinces of each island in Indonesia. In the study by Suharno (2018), only seven provinces as an object of study with monthly data from 2012-2016. They were using the monthly price, which has limitations of the dynamic that happened within a month because beef price volatility happened within a week or a day.

One study by Setiadi et al. (2012) evaluated market integration in a regional beef market in Central Java province using The Johansen cointegration test based on a vector auto-regression (VAR) system to examine market integration. Second, it is still limited to conducting the cointegration of research in the archipelagic state's geographical conditions. Third, the frequency of data used is still low, namely weekly and monthly data. This condition can cause the sensitivity of changes to be less accurate, and changes in the period cannot be adequately known.

In this study, we employed Vector Error Correction Model (VECM) to determine market integration and price transmission and assess the speed of price adjustments of price correction per day and the duration needed until the prices return to equilibrium. As a case from rice, ECM could explore the short-term relationship among prices, comparing before and after trade liberalization by adding a study of price volatility and the influence of government 
intervention (Kustiari and Suhaeti, 1998; Alexander and Wyeth, 1994; Ismet et al. 1998; Ismet and Llewelyn, 2001; Istiqomah et al. 2005; Suryaningrum et al. 2013).

We filled the research gap regarding the market integration to assess domestic markets' integration for beef within an island and between islands and to analyze the speed of adjustment (the correction) of the prices by two provinces within the island and between the island. This study will also contribute to a better understanding of improved strategies for reorienting the marketing system for the author, policymaker, beef farmer, beef trader, beef consumer, and research especially relate to the archipelagic state.

We formulate a certain number of hypotheses: First, the market integration between two provinces within the island is more integrated than two provinces. Second, the speed of adjustment (the correction) of the prices by two provinces within the island is more substantial than between the island.

\section{METHODS}

Consumer prices of beef in different markets in Indonesia is our primary variables of interest collected from the Ministry of Trade, Republic of Indonesia. The data used in this study are Beef Consumer Prices (BCP) from Ministry of Trade Indonesia with the average price of 4 types of beef (Primary Cut, Secondary Cut AB, Meat Manufacturing and Fancy and Variety Meat) (Directorate General of Animal Husbandry) with daily frequency (weekdays) from 01 January 2015 to 27 April 2018. For missing values, we interpolated using linear interpolation. Total observation: 28,611 (867 days x 33 capital cities). The standard price transmission methodology which is the level of hierarchy of market analysis methods (Barrett, 1996) then transfers costs are assumed to be constant.

\section{Unit Root Test}

The Augmented Dickey-Fuller (ADF) test employed for a unit root in all the price series in levels and first different. To receive consistent and reliable results then non-stationary data needs to be transformed into stationary data handled by differencing. In general, if there exist a stationary linear combination of nonstationary random variables, the variables combined are said to be cointegrated.
Lag Identification

Akaike Information Criterion (AIC) is used to identify the structure of a daily percentage price change lag that suggests the choice of a minimum number of explanatory variables to minimise the objective function that trades parsimony against reducing the number of squares.

\section{Cointegration Analysis}

The Johansen test is carried out by using a linear deterministic trend to find out the number of cointegration vectors and the speed of adjustment towards a long-term balance has been determined based on a pairwise relationship between the capital of the provinces. Cointegration relationships in a study are needed for analysis of long-term relationships of reasonable prices.

\section{VECM}

In the fourth step, we estimate the speed of price adjustment for long-run using VECM for the provinces with other provinces. (von Cramon Taubadel, 2017) VECM long-run equilibrium relationship between two prices, so called error correction mechanism that describes how one or both prices react to restore equilibrium whenever it is disturbed by a shock. Engle and Granger (1987) show that if two variables I (1) are cointegrated, there is a need for VECM representation that regulates their standard behavior. The advantage of using VECM that applies to variable I (1) is that the variable can describe the cointegration relationship or long-term equilibrium between these variables. Because price data - as shown above for consumer prices for beef in Indonesia - often displays behavior I (1), and because differences in the dynamics of longterm equilibrium allow easy and intuitive interpretation, VECM has become an established method for price transmission analysis.

The standard VECM equation of price transmission between province A and B beef market prices can be written as:

$\left[\begin{array}{l}\Delta P_{t}^{A} \\ \Delta P_{t}^{B}\end{array}\right]=\beta+\left[\begin{array}{c}\alpha^{A} \\ \alpha^{B}\end{array}\right] \hat{e}_{t-1}+\sum_{d} \Gamma_{d}\left[\begin{array}{l}\Delta P_{t-d}^{A} \\ \Delta P_{t-d}^{B}\end{array}\right]+u_{t}, u_{t} \sim N\left(0, \Sigma_{2 \times 2}\right)$

In equation, Pit is the $(\log )$ of beef market price on two respective provinces $(\mathrm{PA}$ and $\mathrm{PB}, \mathrm{i})$ with at time $\mathrm{t}$, and $\Delta$ is the first difference operator. Each $\Gamma$ is $2 \times$ 
2 matrices of coefficients that relate current price changes to past price changes, where $d$ is the number of lags included in the model. $\beta$ is a $2 \times 1$ vector of constants, and ut is a vector of disturbance terms with mean zero and covariance matrix $\Sigma$. êt-1 is the socalled error correction term that measures deviations from the long-run relationship between PA and PB. In our application, we define êt- 1 as the difference (PA - PB), where PA is a province beef market price, and $\mathrm{PB}$ is the pairwise province beef market price. The larger PA-PB, the higher will be the incentive to trade beef from $\mathrm{B}$ to $\mathrm{A}$. This will, ceteris paribus, reduce $\mathrm{PA}$ and increase $\mathrm{PB}$ and thus drive êt -1 towards zero. $\alpha \mathrm{A}$ and $\alpha \mathrm{B}$ are the so-called adjustment coefficients that measure the 'error correcting' responses of PA and PB to êt -1 . $\alpha \mathrm{A}$ is expected to be negative, as positive values of êt -1 should trigger reductions in PA. By analogous reasoning, $\alpha \mathrm{B}$ is expected to be positive.

A critical limitation of the VECM standard in Equation (1) is its linearity, which is the assumption that the application of error correction to deviations from longterm equilibrium regardless of their sign, magnitude, or when it occurs. There are many situations where this linearity assumption can be challenged. For example, there are illegal fees during the distribution process; there are differences in transportation costs between the two locations according to the season, and the existence of road congestion that affects the duration of the trip. These variations can affect the speed of price shocks transmitted between two locations.

\section{RESULTS}

There are significant influences of distance and logistic effects on the transmission of beef consumer prices between markets among the province and within the province in Indonesia. Of the 33 provinces, there are 28 provinces which are non-stationarity at level and stationarity at the first difference - the results of the ADF unit root test data that we use for the cointegration test stage using the Johansen Cointegration Test. We also can test for cointegration of two variables of different integration, i.e. I (0) vs I (1) -> C (0). Hence, there is a possibility for all 33 provinces. The results of stationarity test that all of price series are stationary in their first difference I(1) is a pre-requisite for the cointegration test. Lag optimal length was estimated before estimating cointegration test. This test was conducted because the result of cointegration test can be quite sensitive to lag length (Suryaningrum et al. 2013). Unit root test result in Table 1.

Table 1. Unit root test result

\begin{tabular}{|c|c|c|c|c|}
\hline \multirow{3}{*}{$\begin{array}{l}\text { Provinces } \\
\text { Aceh }\end{array}$} & \multicolumn{2}{|c|}{ Level } & \multicolumn{2}{|c|}{ First Difference } \\
\hline & \multicolumn{2}{|c|}{ Constant and Trend } & \multicolumn{2}{|c|}{ Constant and Trend } \\
\hline & -34.694 & 0.04525 & -11.353 & 0.01 \\
\hline Medan & -3.454 & 0.04672 & -11.839 & 0.01 \\
\hline Padang & -2.444 & 0.3902 & -9.032 & 0.01 \\
\hline Pekanbaru & -2.986 & 0.1608 & -11.729 & 0.01 \\
\hline Jambi & -4.167 & 0.01 & -13.318 & 0.01 \\
\hline Palembang & -3.712 & 0.02336 & -12.235 & 0.01 \\
\hline Bengkulu & -35.429 & 0.03818 & -12.02 & 0.01 \\
\hline Lampung & -2.948 & 0.177 & -13.921 & 0.01 \\
\hline Jakarta & -2.80 & 0.2392 & -11.225 & 0.01 \\
\hline Bandung & -22.902 & 0.4555 & -11.445 & 0.01 \\
\hline Semarang & -3.922 & 0.01288 & -10.411 & 0.01 \\
\hline Yogyakarta & -2.014 & 0.5723 & -11.846 & 0.01 \\
\hline Surabaya & -25.139 & 0.3608 & -7.297 & 0.01 \\
\hline Denpasar & -3.67 & 0.02527 & -9.507 & 0.01 \\
\hline Mataram & -3.44 & 0.04807 & -10.903 & 0.01 \\
\hline Kupang & -1.62 & 0.7384 & -11.42 & 0.01 \\
\hline Gorontalo & -3.579 & 0.03468 & -10.179 & 0.01 \\
\hline Pontianak & -3.009 & 0.1508 & -11.49 & 0.01 \\
\hline Palangkaraya & -3.439 & 0.04811 & -10.63 & 0.01 \\
\hline Banjarmasin & -3.332 & 0.06509 & -12.36 & 0.01 \\
\hline Samarinda & -2.407 & 0.406 & -10.17 & 0.01 \\
\hline Manado & -3.421 & 0.04985 & -11.02 & 0.01 \\
\hline Palu & -3.84 & 0.01679 & -12.26 & 0.01 \\
\hline Makassar & -3.52 & 0.04024 & -12.55 & 0.01 \\
\hline Kendari & -15.128 & 0.7845 & -10.227 & 0.01 \\
\hline Ambon & -6.677 & 0.01 & -12.97 & 0.01 \\
\hline Jayapura & -3.58 & 0.03438 & -9.59 & 0.01 \\
\hline Banten & -31.338 & 0.09933 & -10.775 & 0.01 \\
\hline $\begin{array}{l}\text { Bangka } \\
\text { Belitung }\end{array}$ & -49.439 & 0.01 & -13.196 & 0.01 \\
\hline $\begin{array}{l}\text { Maluku } \\
\text { Utara }\end{array}$ & -3.07 & 0.1245 & -12.90 & 0.01 \\
\hline Mamuju & -4.3 & 0.01 & -11.64 & 0.01 \\
\hline Manokwari & -2.087 & 0.5411 & -9.164 & 0.01 \\
\hline $\begin{array}{l}\text { Tanjung } \\
\text { Pinang }\end{array}$ & -4.549 & 0.01 & -11.26 & 0.01 \\
\hline
\end{tabular}




\section{Cointegration Test}

Cointegration testing is divided into two relationships: the relationship pairs of prices within the island and the relationship between islands. Johansen's cointegration test results show that the full trace and eigenvalues are significant at the first rank level. The results are presented in appendices. Both results are similar, the trace test is calculated, and the maximum Eigen test statistics are more significant than the critical values at the $5 \%$ probability level. This further confirms the existence of at least one cointegration relationship between the specified price variables.

The Johansen cointegration testresults further reaffirmed a potential stable long-run relationship between the price of beef on 33 pairwise capital of the provinces among the country. The long run cointegration test results reported in Tables 2 and 3. Again, the critical value at the $5 \%$ level. Suppose the ADF test value is higher than the critical value. In that case, we can reject the null hypothesis that there is no long run cointegration relationship at the $5 \%$ level and conclude that the pair of regional markets are cointegrated. Among 96 pairwise cities with ties trade cointegration of beef in Indonesia, only $72 \%$ (69 pairwise) have long-run relationships.

There is a 31 pairwise integrated market within an island and 38 pairwise integrated markets between the islands. In general, western Indonesia (Kawasan Barat Indonesia-KBI) dominates the integrated relationship compared with provinces in eastern Indonesia (Kawasan Timur Indonesia-KTI). This finding is consistent with Mappamiring (2006), who started a development gap in infrastructure and regional development. The eastern region is less prioritized than Indonesia's western region, so the eastern Indonesian region is less integrated than the western.

For the pairwise within an island, Sumatera has 15 integrated pairwise, then Java with nine integrated pairwise and the rest of others integrated pairwise. Surabaya is the most integrated, namely by 13 other cities, followed by Lampung with 12 relationships and Jakarta with 11 relationships.

\section{VECM}

There is a division of relations when analyzing the VECM relationship, namely VECM relations within the island and between the islands. We can find out the uniqueness and characteristics of The Archipelagic State, such as Indonesia, divided into areas from land and sea and a vast expanse of land from the west to the east. Apart from the distance and mode of transportation, the difference time is also applied to Indonesia, which has three different time zones.

Pairwise that can be known the magnitude of price correction that obtained from VECM method in daily is only the pairwise which match with the ideal criteria such as has a negative value at the first column and positive value at the second column because both of value correcting each other into the equilibrium and also both of them have to be significant. There are 45 ideals pairwise of 69 integrated pairwise $(65.2 \%)$ that can be analyzed for the value of correction daily and the duration needed to correct the price.

Transmission prices corrected between two market price increases in one market in the province within an island to return to the correction punctuated need every day to respond from a price change. The price correction varies with the highest percentage of correction in Jambi and Palembang $22.1 \%$ per day. The lowest or correction can be at least in responding to the Yogyakarta and Semarang only by $3.1 \%$ per day (Table 2).

The average of price correction occurring in pairs provincial in an island that is $10.33 \%$ per day. What was happening with the correction might weaken price made the two provincial back alternations of a specific duration of time depending on big or small the correction every day. It takes an average of eight days with the lowest duration of four days on the market relations between Jambi with Lampung and Jambi with Palembang. Provincial pairs with a long-run relationship, the percentage of price correction per day will be small so that the duration of price correction will be longer. 
Table 2. Pairwise correction per day and duration for correction within island

\begin{tabular}{lccc}
\hline Pairwise & Location & Correction per day (\%) & Duration for correction (days) \\
\hline Aceh - Medan & Sumatera & 9.3 & 7 \\
Padang - Medan & Sumatera & 11 & 6 \\
Padang - Pekanbaru & Sumatera & 7 & 9 \\
Padang - Lampung & Sumatera & 13.1 & 5 \\
Pekanbaru - Lampung & Sumatera & 10.8 & 6 \\
Jambi - Bengkulu & Sumatera & 12.1 & 6 \\
Jambi - Lampung & Sumatera & 17.2 & 4 \\
Jambi - Palembang & Sumatera & 22.1 & 4 \\
Palembang - Lampung & Sumatera & 15.8 & 5 \\
Jakarta - Yogyakarta & Java & 3.8 & 15 \\
Jakarta - Surabaya & Java & 4.9 & 12 \\
Bandung - Jakarta & Java & 6.3 & 10 \\
Yogyakarta - Semarang & Java & 3.1 & 17 \\
Banten - Semarang & Java & 5.8 & 10 \\
Gorontalo - Palu & Sulawesi & 5.1 & 12 \\
Makassar - Kendari & Sulawesi & 13.7 & 5 \\
Banjarmasin - Pontianak & Kalimantan & 14.7 & 5 \\
Mataram - Kupang & Nusa Tenggara & 10.1 & 6 \\
\hline
\end{tabular}

Meanwhile, the most extended duration needed to emend return to punctuated is Yogyakarta's relations with Semarang, which was for 17 days. On the Sumatra island, of the nine couples, the average time required for correction is around six days with a correction of $10.2 \%$ per day and on the Java island with five couples need on average 13 days for mutual are correcting with the value of the percentage correction every day which is $4.78 \%$. Two couples who stay in Sulawesi Island have an average of $9.4 \%$ every day, so the average duration needed is 8.5 days. To Kalimantan and Nusa Tenggara, each of them needs five days and six days for correction with the value of the percentage of correction, namely $14.7 \%$ and $10.1 \%$.

The relationship of different provinces located between the islands has a difference from the relations of two provinces within an island. The analysis results showed that correction the price of each day on average is $9.87 \%$, and the duration, on average, is 9.52 days, at least $1.3 \%$ at the nexus of Manokwari and Ambon. In comparison, correction per day, which is $20.3 \%$ in Bangka Belitung and Surabaya. The shortest average duration correction is four days in Jambi and Bandung, Bangka Belitung and Surabaya, Banjarmasin and Surabaya, and Banjarmasin and Mataram. While the most extended correction is between Manokwari and Ambon, namely 32 days, and the next relation is between Samarinda and Gorontalo by 27 days and that you see in Table 3 .

The most owned relationship is between Sumatra and Java, with ten couples. Duration needed for mutual emend on equilibrium on average is six days, with the value of the correction on average is $12.4 \%$ per day. Followed by four pairwise between Java and Kalimantan with the duration, 5.25 days with the correction on average is $14.07 \%$ per day. Kalimantan and Nusa Tenggara also have four pairwise with a duration; on average, 7.25 days with the correction is $10.025 \%$ per day.

On average, a pair of Java and Sulawesi has a shorter duration and more extensive corrections than Kalimantan and Sulawesi, which is nine days than eighteen days and $7.45 \%$ per day than $4.1 \%$ per day. This thing can be known that the couple market can more quickly correct Sulawesi's response regarding price changes in Java instead of Kalimantan because the relationship among them is in the short run. The couple between Java and Nusa Tenggara, Papua and Maluku had more time between 12 to 32 days with the correction from $1.3 \%$ to $4.8 \%$ per day. 
Table 3. Pairwise correction per day and duration for correction between islands

\begin{tabular}{|c|c|c|c|}
\hline Pairwise & Location & Correction per day (\%) & Duration for correction (days) \\
\hline Pekanbaru - Jakarta & Sumatera - Java & 10 & 6 \\
\hline Pekanbaru - Surabaya & Sumatera - Java & 6 & 10 \\
\hline Jambi - Jakarta & Sumatera - Java & 13.9 & 5 \\
\hline Jambi - Bandung & Sumatera - Java & 19.1 & 4 \\
\hline Jambi - Surabaya & Sumatera - Java & 12.6 & 5 \\
\hline Palembang - Jakarta & Sumatera - Java & 12.5 & 5 \\
\hline Palembang - Surabaya & Sumatera - Java & 11.5 & 6 \\
\hline Lampung - Surabaya & Sumatera - Java & 7.8 & 9 \\
\hline Banten - Lampung & Sumatera - Java & 10.3 & 6 \\
\hline Bangka Belitung - Surabaya & Sumatera - Java & 20.3 & 4 \\
\hline Bandung - Kupang & Java - Nusa Tenggara & 2.1 & 26 \\
\hline Bandung - Makassar & Java - Sulawesi & 5.2 & 12 \\
\hline Makassar - Jakarta & Java - Sulawesi & 9.7 & 6 \\
\hline Pontianak - Surabaya & Java - Kalimantan & 15.1 & 5 \\
\hline Palangkaraya - Surabaya & Java - Kalimantan & 10.4 & 6 \\
\hline Banjarmasin - Jakarta & Java - Kalimantan & 11.1 & 6 \\
\hline Banjarmasin - Surabaya & Java - Kalimantan & 19.7 & 4 \\
\hline Banjarmasin - Mataram & Kalimantan - Nusa Tenggara & 17.2 & 4 \\
\hline Palangkaraya - Kupang & Kalimantan - Nusa Tenggara & 9.5 & 6 \\
\hline Samarinda - Mataram & Kalimantan - Nusa Tenggara & 7.7 & 9 \\
\hline Samarinda-Kupang & Kalimantan - Nusa Tenggara & 5.7 & 10 \\
\hline Palangkaraya - Makassar & Kalimantan - Sulawesi & 7.4 & 9 \\
\hline Samarinda - Gorontalo & Kalimantan - Sulawesi & 1.9 & 27 \\
\hline Samarinda - Palu & Kalimantan - Sulawesi & 3 & 17 \\
\hline Makassar - Kupang & Sulawesi-Nusa Tenggara & 10.9 & 6 \\
\hline Manokwari - Ambon & Papua - Maluku & 1.3 & 32 \\
\hline Manokwari - Maluku Utara & Papua - Maluku & 4.8 & 12 \\
\hline
\end{tabular}

Changes in Jakarta's beef prices have been responded slowly by other provinces such as Yogyakarta and Surabaya, namely 15 days and 12 days. Meanwhile, if there is a price change in other provinces, Jakarta responds quickly, which is under six days, so that Jakarta has been affected by the other regions and not vice versa. This is supported by the fact that the majority of beef imports from abroad enter through Jakarta. Import needs are influenced by the Indonesian consumption level, domestic price, and imported meat price. The higher meat consumption level in Indonesia would increase imported meat volume, especially if it were not balanced with domestic supply. The higher domestic meat price and the lowest imported meat price would increase import volume (Destiarni, 2016).

\section{Managerial Implications}

KBI has more cointegration relationships than KTI. Two things that could be an improvement to fill this gap are the construction of a new beef production center close to the market in eastern Indonesia, the Price Information System, and the development of frozen beef.

Jakarta as the market center in KBI affects market integration and price transmission in other provinces. Due to Indonesia's geographic factors which are spread out and divided into land and water areas, the government can think about supporting the establishment of a central beef market in eastern Indonesia that can be closer to domestic and foreign market access, namely in Makassar so that the need for beef in KTI can be more affordable for the speed of price and delivery. 
In the era of technology and information that is increasingly accessible, the government can create a price information system located in central market each provinces, so the market will be backed up with data and information on decision to purchase beef based on optimal distance logarithms that can traveled by traders. On the other hand, the cost efficiency of transportation can be achieved by distributing frozen beef. With the Covid-19 pandemic, the demand for frozen food has increased so that fresh meat is not always the consumer's choice.

\section{CONCLUSIONS AND RECOMMENDATIONS}

\section{Conclusions}

The provinces located within the island have fewer integrated than the couple's provinces between islands by comparing 31 pairs with 38 couples. Understandably, trade relations with a province on another island are more varied than those on an island. Interestingly, Sumatera being an island related integrated most.

Itcan beconcluded that fromresearch, theprice correction in the pairwise province within an island is stronger than the pairwise between the islands with $10.33 \%$ per day and $9.87 \%$ per day, respectively. The duration of the pairwise correction within an island is faster than the pairwise between the islands with, on average, eight days and, on average, 9.52 days, respectively. Based on these findings, this study recommends the government to formulate policies that carry out equitable development, especially those that facilitate access to the central beef production in Indonesia to avoid market exploitation and spread price information along with provinces in Indonesia, especially in eastern Indonesia. This will help in enhancing the efficiency of the marketing system in agricultural commodities and reduce market distortions.

\section{Recommendations}

Finally, further research involves several factors that will influence others, such as transaction cost, transfer cost, and flow trade, to better understand Indonesia's beef market. Also, need to develop some understanding on the market integration to test causality to know which province had more influence in the price correction and can be used the culture others are better than consumption patterns local people and relation to the celebration of a religious holiday, center of the production of beef, the distance, transportation, logistic, and things more politically like the government.

\section{REFERENCES}

Acquah HD, Owusu R. 2012. Spatial market integration and price transmission of selected plantain markets in Ghana. Journal of Sustainable Development in Africa 14(5): 208-217

Alexander C, Wyeth J. 1994. Cointegration and market integration: an application to the Indonesian rice market. Journal of Development Studies 30(2): 303-328. https://doi. org/10.1080/00220389408422317.

Barrett CB. 1996. Market analysis methods: are our enriched toolkits well suited to enlivened markets? American Journal of Agricultural Economics 78(3): 825-829. https://doi. org/10.2307/1243313.

Chalil D. 2016. Sustainability of sustainable palm oil: a market integration analysis. Jurnal Manajemen \& Agribisnis 13(2): 157-167. https://doi. org/10.17358/JMA.13.2.157.

Dewi I. 2016. Price volatility analysis in Indonesian beef market [Thesis]. Bogor: Graduate School. Bogor Agricultural University.

Destiarni, R. 2016. Analisis permintaan daging sapi impor Indonesia [Thesis]. Bogor: Graduate School. Bogor Agricultural University.

Engle R, Granger C. 1987. Cointegration and Error Correction Representation, Estimation and Testing. Econometrica: journal of the Econometric Society 55: 251-276. https://doi. org/10.2307/1913236.

Firdaus M, Gunawan I. 2012. Integration among regional vegetable markets in Indonesia. Journal of ISSAAS (The International Society for Southeast Asian Agriculture Sciences) 18(2):96106.

Indonesian Ministry of Agriculture. 2017. Agricultural Data Center and Information System: Beef Outlook. Jakarta: Indonesian Ministry of Agriculture.

Ismet M, Barkley AP, Llewelyn RV. 1998. Spatially linked pricing dynamics in Indonesian rice markets. Journal of Agricultural Economics 19: 283-295. https://doi.org/10.1111/j.1574- 
0862.1998.tb00532.x.

Ismet M, Llewelyn RV. 2001. Market integration in regional Indonesian rice markets. Economic and Financial Indonesia 49(1): 17-46.

Istiqomah, Zeller M., Von Cramon-Taubadel S. 2005. Volatility and Integration of Rice Markets in Java, Indonesia: A Comparative Analysis before and after Trade Liberalisation. Tropentag Paper.

Krishna A. 2004. Escaping poverty and becoming poor: Who gains, who loses, and why? World Development 32 (1): 121-136. https://doi. org/10.1016/j.worlddev.2003.08.002.

Kustiari R and Suhaeti RN. 1998. Rice market integration in Indonesia: a cointegration analysis. Agro Economic Journal 17(1).

Listorti G. Esposti R. 2012. Horizontal price transmission in agricultural markets: fundamental concepts and open empirical issues. Bio-based and Applied Economics 1(1): 81-96

Mappamiring. 2006. PerspektifAlternatifPembangunan Kawasan Timur Indonesia. Jurnal Penyuluhan 2(4): 58-61. https://doi.org/10.25015/ penyuluhan.v2i4.2116.

Nurhidayati I, Hakim DB, Asmara A. 2015. Integrasi pasar karet alam sit asap antara produsen utama dengan pasar berjangka dunia. Jurnal Manajemen \& Agribisnis 12(3): 204-216. https:// doi.org/10.17358/JMA.12.3.204.

Rahmawati A, Fariyanti A, Rifin A. 2018. Spatial market integration of shallot in Indonesia. Jurnal Manajemen \& Agribisnis 15(3): 258-268. https:// doi.org/10.17358/jma.15.3.258.
Setiadi A. Sunarso, Lantican, FA, De Castro NL. 2012. Spatial integration of beef markets at the retail level in Central Java, Indonesia. Philippine Journal of Veterinary and Animal Sciences 38 (1): 97-106.

Setianti C, Ekowati T, Setiadi A. 2017. Market integration of fresh milk in the dairy business area of Pamijahan district and Cisarua district, Bogor regency -Indonesia. Journal of the Indonesian Tropical Animal agriculture: 42-47.

Suharno. 2018. Spatial market integration and price transmission of meat in Indonesia. 10th International Conference of Agricultural Economist. IAAE. Vancouver, Canada.

Suryaningrum DA, Chang, Wen-I, Anindita R. 2013. Analysis of spatial integration of Thailand and Vietnam rice market in Indonesia. Greener Journal of Business and Management Studies 3 (7): 333-342.

Utami AD. 2016. Price Formation in the Indonesian Beef Industry: The Role of Policy Intervention [Dissertation]. Goettingen University.

Varela G, Aldaz-Carrol E, Iacovone L. 2012. Determinants of Market Integration and Price Transmission in Indonesia. The World Bank: Policy Research Working Paper 6098.

Von Cramon-Taubadel S. 2017. The analysis of market integration and price transmission - results and implications in an African context, Agrekon 56(2): 83-96, DOI: 10.1080/03031853.2017.1295655

World Bank. 2017. Land area. https://data.worldbank. org/indicator/ag.lnd.totl.k2 on [23 Aug 2018]. 